\title{
Peningkatan Kadar Feritin Serum Memiliki Korelasi Negatif dengan Kadar High Density Lipoprotein pada Anak Penyandang Thalassemia Beta Mayor
}

Nelly Rosdiana, Christian Nasir

Bagian Ilmu Kesehatan Anak Fakultas Kedokteran Universitas Sumatera Utara /RSUP Haji Adam Malik, Medan

Latar belakang. Komplikasi dari thalassemia beta mayor disebabkan akumulasi zat besi yang diukur melalui pemeriksaan feritin. Penyandang thalassemia beta mayor juga mengalami gangguan profil lipid akibat kelebihan zat besi. Namun, penelitian mengenai hubungan mengenai feritin dengan profil lipid masih terbatas dan berbeda-beda hasilnya.

Tujuan. Mengetahui pengaruh kadar feritin serum terhadap kadar profil lipid pada anak penyandang thalassemia beta mayor

Metode. Penelitian berupa studi analitik observasional dengan desain potong lintang, menganalisis korelasi antara kadar feritin serum dengan profil lipid (kolesterol total, trigliserida, HDL, dan LDL) pada anak penyandang thalassemia beta mayor. Dilakukan pada bulan Januari - April 2018. Uji statistik menggunakan uji korelasi Spearman. Tingkat kemaknaan dinyatakan dengan p $<0.05$. Hasil. Subjek 49 orang, rentang usia 1,6-17,9 tahun. Jenis kelamin terbanyak adalah perempuan (55\%). Terdapat korelasi bermakna antara kadar feritin serum dengan kadar HDL $(r=-0,317, p=0,026)$. Tidak terdapat korelasi bermakna antara kadar feritin serum dengan kadar kolesterol total, trigliserida, dan LDL ( $\mathrm{p}<0,05)$.

Kesimpulan. Terdapat korelasi negatif yang bermakna antara kadar feritin serum dengan kadar HDL pada penyandang thalassemia beta mayor. Sari Pediatri 2019;21(1):31-6

Kata kunci: kadar feritin, profil lipid, thalassemia beta mayor

\section{Serum Ferritin has Inverse Correlation with High Density Lipoprotein Level in Children with Beta Thalassemic Major}

Nelly Rosdiana, Christian Nasir

Background. Complications in beta thalassemic major is caused by iron accumulation, which measured by serum ferritin. Children with beta thalassemic major also have lipid profiles abnormality, which related to iron overload. The studies regarding association between serum ferritin and lipid profiles were still limited and gave contradictory resuts.

Objective. To determine the correlation between serum ferritin and lipid profiles in children with beta thalassemic major

Methods. This was an observational study with cross-sectional design, analyzing the correlation between ferritin serum and lipid profiles (total cholesterol, triglyceride, HDL, and LDL) in children with beta thalassemic major, from January to April 2018. Statistical significance was set at $\mathrm{p}<0.05$.

Result. There were 49 subjects, age between 1.6 and 17.9 years old. The majority of the subjects is female (55\%). There was significant correlation between ferritin serum and HDL level $(\mathrm{r}=-0.317, \mathrm{p}=0.026)$. There were no significant correlation between ferritin serum and total cholesterol, triglyceride, and LDL $(\mathrm{p}<0.05)$.

Conclusion. There was significant inverse correlation between serum ferritin and HDL level in children with beta thalassemic major. Sari Pediatri 2019;21(1):31-6

Keywords: serum ferritin, lipid profiles, beta thalassemic major

Alamat korespondensi: Nelly Rosdiana. Rumah Sakit Umum Pusat Haji Adam Malik, Jl. Bunga Lau No. 17, Medan Telpon/Fax. Email: nelly_hemato@ yahoo.com 
T halassemia merupakan penyakit genetik yang disebabkan oleh gangguan produksi rantai globin. Pada individu dengan thalassemia beta, dapat terjadi kehilangan total dari rantai globin $\beta$ (thalassemia mayor) atau kehilangan sebagian dari rantai globin $\beta$ (thalassemia minor). ${ }^{1}$ Thalassemia beta mayor memerlukan transfusi darah secara teratur untuk mengatasi gejala klinis yang sering terjadi. ${ }^{2}$ Komplikasi umumnya terjadi karena akumulasi zat besi di jantung, hati, dan organ-organ endokrin. ${ }^{3}$ Kadar zat besi yang tinggi di dalam darah akan menyebabkan peningkatan risiko terjadinya atherosklerosis melalui peningkatan zat radikal bebas. ${ }^{4}$ Selain itu, anak dengan thalassemia beta juga memiliki risiko atherosklerosis prematur sebagai akibat dislipidemia. ${ }^{3}$

Beberapa penelitian telah menunjukkan bahwa akumulasi zat besi di tubuh dapat menimbulkan gangguan profil lipid. ${ }^{5-7}$ Penyandang thalassemia mengalami gangguan profil lipid dalam bentuk kadar kolesterol total, High Density Lipoprotein (HDL), dan Low Density Lipoprotein (LDL) yang lebih rendah serta kadar trigliserida yang lebih tinggi dibandingkan individu normal. ${ }^{8}$ Dislipidemia pada thalassemia mayor disebabkan oleh berbagai faktor, antara lain dilusi plasma akibat anemia, meningkatnya aktivitas eritropoeisis yang disertai dengan pengambilan kolesterol oleh makrofag dan histiosit dalam sistem retikuloendotelial, gangguan fungsi hati karena penimbunan zat besi, gangguan hormonal, dan menurunnya aktivitas lipolisis di luar hati. ${ }^{4}$

Gambaran profil lipid pada thalassemia memiliki korelasi dengan penumpukan zat besi di dalam darah. Penumpukan zat besi di dalam hati akan menimbulkan kerusakan hepatosit dan sel retikuloendotelial, yang ditandai oleh perkembangan fibrosis hingga terjadi sirosis. Kerusakan hati dihubungan dengan kadar kolesterol total, HDL, dan LDL yang rendah. ${ }^{5}$ Pengukuran terhadap kadar zat besi di tubuh manusia dilakukan melalui pemeriksaan kadar feritin serum. Feritin adalah kerangka protein intraselular yang terdiri dari 24 subunit yang mengelilingi inti besi yang mengandung sekitar 4000-4500 atom besi. ${ }^{9}$

Beberapa penelitian sebelumnya tidak menunjukkan hubungan yang konsisten antara kadar feritin serum dan profil lipid pada anak penyandang thalassemia beta mayor. Penelitian oleh Suman menunjukkan bahwa feritin memiliki korelasi positif dengan kadar trigliserida. Peningkatan kadar feritin serum akan diikuti oleh peningkatan kadar trigliserida. Sebaliknya terdapat korelasi negatif antara kadar feritin serum dengan kolesterol total, HDL, dan LDL. ${ }^{5}$ Walaupun demikian, penelitian oleh Hassanin menunjukkan bahwa feritin tidak memiliki korelasi yang bermakna dengan kadar trigliserida. Namun, kadar Feritin serum memiliki korelasi positif dengan LDL dan korelasi negatif dengan HDL. ${ }^{7}$ Penelitian oleh Sayed hanya menunjukkan adanya korelasi positif antara feritin dan kadar trigliserida, namun tidak ada korelasi yang bermakna dengan profil lipid lainnya. ${ }^{11}$

Hingga saat ini, belum tersedia data mengenai hubungan antara Feritin dan profil lipid pada penyandang thalassemia beta mayor di Indonesia. Tujuan dari penelitian ini adalah untuk mengetahui pengaruh feritin terhadap profil lipid pada anak penyandang thalassemia beta mayor.

\section{Metode}

Rancangan penelitian ini adalah uji analitik observasional dengan desain potong lintang. Pengambilan sampel dilakukan dari anak penyandang thalassemia yang menjalani transfusi darah rutin di unit One Day Care RSUP H. Adam Malik, mulai Januari 2018- April 2018. Kriteria inklusi adalah penyandang thalassemia beta mayor berdasarkan data rekam medis pasien, berusia di bawah 18 tahun, dan bersedia untuk terlibat dalam penelitian. Kriteria eksklusi adalah penyandang thalassemia yang telah mengonsumsi obat anti dislipidemia, baik golongan statin maupun golongan fibrat. Penelitian ini telah memperoleh persetujuan dari komite etik Fakultas Kedokteran Universitas Sumatera Utara, Medan dan RSUP H. Adam Malik, Medan.

Dilakukan pengambilan data dari rekam medis yang meliputi diagnosis, jenis kelamin, dan usia penyandang thalassemia. Pengukuran berat badan dan tinggi badan dari subjek penelitian dilakukan sebelum pemeriksaan darah. Sehari sebelum pemeriksaan profil lipid, subjek penelitian diingatkan melalui telepon untuk puasa 10-12 jam sebelum pengambilan darah di pagi hari.

Pengambilan darah dilakukan dari vena sebanyak $6 \mathrm{ml}$, di mana $3 \mathrm{ml}$ darah dimasukkan dalam tabung berisi ethylene diamine tetra acetic acid (EDTA) untuk pemeriksaan darah rutin dan sisanya dimasukkan ke dalam tabung serum untuk pemeriksaan feritin dan profil lipid. Pengukuran kadar feritin dilakukan 
menggunakan metode eletrochemiluminescence immunoassay (ECLIA) dengan menggunakan instrumen Cobas (ROCHE). Pengukuran kadar trigliserida dilakukan dengan menggunakan metode glycerol phosphate oxidase dan kadar kolesterol total diukur dengan metode enzimatik. Sedangkan, kadar LDL diukur dengan metode liquid selective detergentdan kadar HDL diukur dengan metode acceleratorselective detergent. Pemeriksaan profil lipid dilakukan dengan menggunakan instrumen Architect (ABBOTT).

Analisis statistik dilakukan dengan menggunakan software SPSS versi 20. Data yang memiliki sebaran normal akan ditampikan dalam bentuk rerata dan simbangan baku. Sedangkan, data yang tidak memiliki sebaran normal akan ditampilkan dalam bentuk median dan rentang nilai minimum-maksimum. Variabel independen adalah kadar feritin serum dan variabel dependen adalah profil lipid. Korelasi antara kadar feritin serum dan profil lipid dilakukan dengan menggunakan uji statistik Pearson bila variabel berdistribusi normal dan uji Spearman bila data tidak berdistribusi normal. Tingkat kemaknaan dalam penelitian ini dinyatakan bila $\mathrm{p}<0,05$.

Besar korelasi secara statistik dinyatakan sebagai sangat lemah $(0-<0,2)$, lemah $(0,2-<0,4)$, sedang $(0,4-$ $<0,6)$, kuat $(0,6-<0,8)$, dan sangat kuat $(0,8-<1)^{10}$

\section{Hasil}

Subyek penelitian didapatkan sebanyak 49 anak penyandang thalassemia beta mayor yang memenuhi kriteria inklusi. Terdapat 45 anak yang memiliki kadar serum feritin di atas $1000 \mathrm{ng} / \mathrm{mL}$. Rentang usia penyandang thalassemia beta mayor dalam penelitian ini adalah 1,6 - 17,9 tahun, dengan mayoritas subjek berjenis kelamin perempuan (55\%).

Profil klinis, antropometrik, dan hasil laboratorium pada penelitian ini tertera pada Tabel 1. Hasil laboratorium untuk feritin, trigliserida, dan kolesterol disajikan dalam bentuk median dan rentang nilai maksimum-minimum karena distribusi data yang tidak normal. Data kolesterol total dan HDL disajikan dalam bentuk rerata dan simpangan baku karena memiliki distribusi data yang normal.

Subjek penelitian memiliki kadar feritin yang tinggi dengan median $2000 \mathrm{ng} / \mathrm{mL}$. Terapi kelasi telah diberikan pada subjek penelitian dengan kadar feritin di atas $1000 \mathrm{ng} / \mathrm{mL}$. Pada penelitian ini, didapatkan bahwa rerata atau median dari profil lipid pada anak penyandang thalassemia beta mayor berada dalam rentang normal, kecuali pada kadar HDL. Rerata dari kadar HDL yaitu 22,2 $\mathrm{mg} / \mathrm{dL}$ berada di bawah normal $(<40 \mathrm{mg} / \mathrm{dL})$.

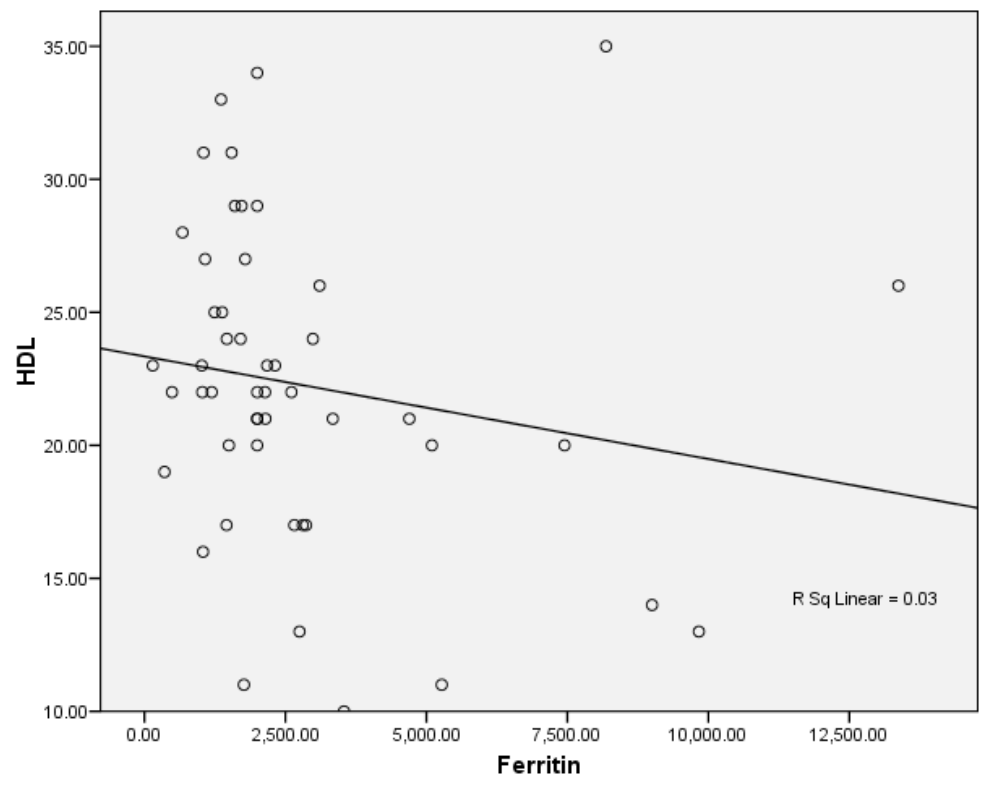

Gambar 1. Grafik scatter yang menggambarkan hubungan antara kadar feritin terhadap kadar HDL 
Tabel.1 Karakteristik dasar subjek penelitian

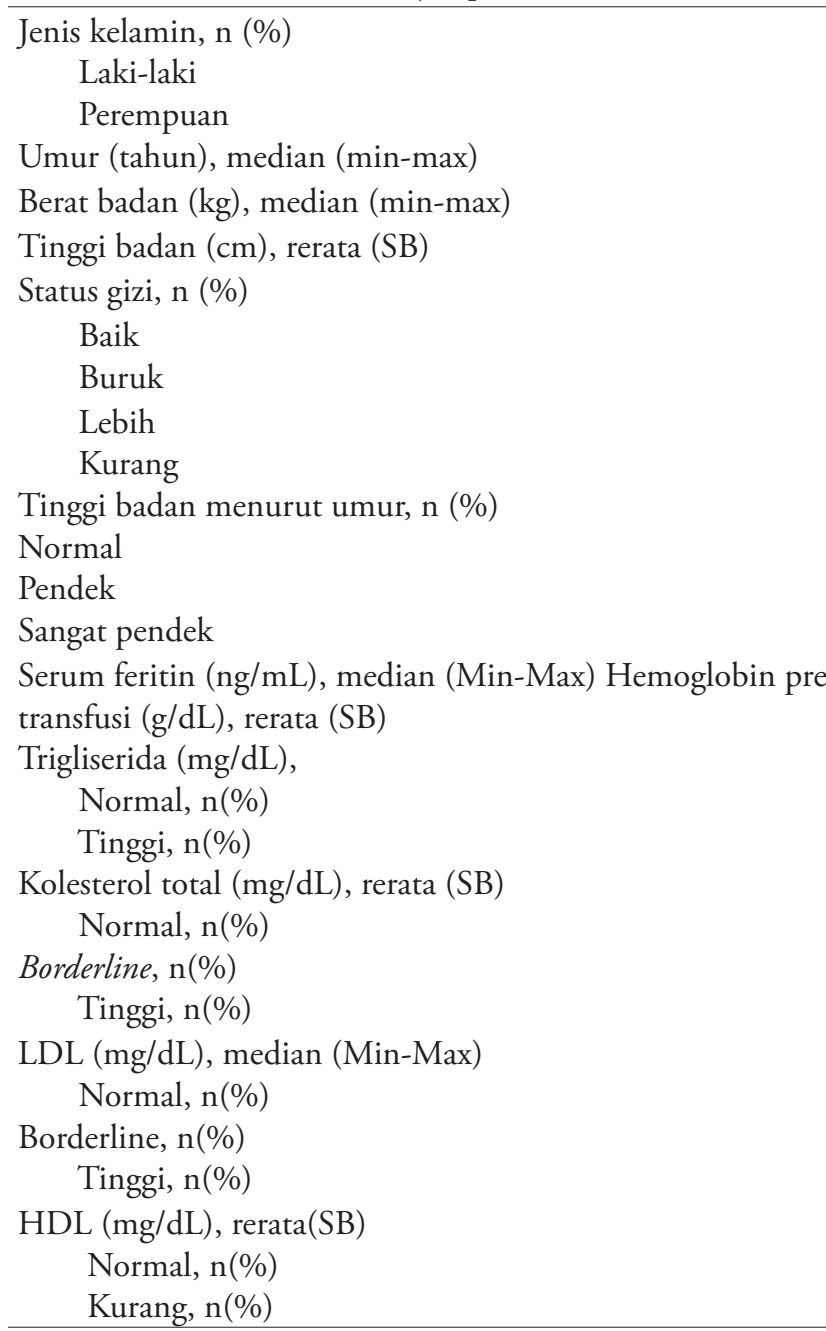

$\mathrm{n}=49$

$22(45)$

$27(55)$

$10,5(1,6-17,9)$

23 (10-61)

$122,2( \pm 23)$

$24(49)$

$22(45)$

2 (4)

1 (2)

$17(35)$

$31(63)$

$1(2)$

$2000(146,7-13371,95)$

$6,9( \pm 1,3)$

$112(64-287)$

$37(75,5)$

$12(24,5)$

$93,9( \pm 21,6)$

$49(100)$

$0(0)$

$0(0)$

58 (24-173)

$45(92)$

2 (4)

2 (4)

$22,2( \pm 5,9)$

$0(0)$

$49(100)$

Tabel 2. Korelasi antara feritin serum dengan profil lipid

\begin{tabular}{cccccc}
\hline & & Trigliserida & Kolesterol total & HDL & LDL \\
\hline Feritin & $\mathrm{r}$ & 0,200 & $-0,079$ & $-0,317$ & $-0,223$ \\
& $\mathrm{p}$ & 0,168 & 0,591 & 0,026 & 0,123 \\
& $\mathrm{n}$ & 49 & 49 & 49 & 49 \\
\hline
\end{tabular}

Uji korelasi Spearman

Interval Kepercayaan $95 \%$

Korelasi antara feritin dan profil lipid diukur menggunakan uji statistik Spearman karena sebaran data tidak normal. Tidak terdapat korelasi yang bermakna antara kadar serum feritin dengan kadar kolesterol total, trigliserida, dan LDL yang tertera pada Tabel 2. Namun, terdapat korelasi negatif yang bermakna antara feritin dengan kadar HDL. Besar korelasi yang didapat sebesar $-0,317$ menunjukkan adanya korelasi lemah, di mana setiap peningkatan kadar feritin serum akan diikuti oleh penurunan kadar HDL. Grafik scatter pada gambar 1 menunjukkan adanya korelasi yang bersifat negatif antara kadar feritin dan kadar HDL

\section{Pembahasan}

Penyandang thalassemia beta memiliki gangguan profil 
lipid atau dislipidemia dalam bentuk kadar kolesterol total, HDL, dan LDL yang rendah; serta kadar trigliserida yang lebih tinggi dibandingkan individu normal. ${ }^{6,11,12}$ Dislipidemia pada thalassemia disebabkan beberapa faktor, antara lain dilusi plasma akibat anemia dan meningkatnya aktivitas eritropoeisis. ${ }^{4}$ Subjek penelitian memiliki kadar Hemoglobin pre transfusi yang rendah yaitu $6,9 \pm 1,3 \mathrm{~g} / \mathrm{dL}$. Aktivitas eritropoeisis yang meningkat akan menimbulkan pengambilan kolesterol oleh makrofag dan histiosit dalam sistem retikuloendotelial. ${ }^{4}$

Pada penelitian ini, ditemukan rerata atau median dari kadar kolesterol total, trigliserida, dan LDL yang masih dalam rentang normal, namun rerata kadar HDL berada di bawah normal $(<40 \mathrm{mg} / \mathrm{dL})$ yaitu $22,2 \pm 5,9 \mathrm{mg} / \mathrm{dL}$.

Berbeda dengan penelitian sebelumnya, penelitian ini tidak menunjukkan kadar trigliserida yang tinggi $(>150 \mathrm{mg} / \mathrm{dL}$ ) pada penyandang thalassemia beta mayor. Penelitian di India, Mesir, Yordania, dan Turki menunjukkan kadar trigliserida yang lebih tinggi pada penyandang thalassemia mayor dibandingkan individu normal..$^{5,6,11,13} \mathrm{Hal}$ ini berhubungan dengan menurunnya aktivitas lipolisis di luar hati pada penyandang thalassemia beta mayor. ${ }^{5,6}$ Penelitian lain di Iran dan Italia tidak menunjukkan adanya perbedaan kadar trigliserida yang bermakna antara penyandang thalassemia dan populasi anak sehat. ${ }^{14,15}$ Data mengenai profil lipid pada penyandang thalassemia di kawasan Asia Tenggara belum tersedia sebagai data pembanding untuk penelitian ini.

Pada penelitian ini, subjek penelitian memiliki kadar feritin yang tinggi hingga 13371,95 ng/mL dengan median $2000 \mathrm{ng} / \mathrm{mL}$. Kadar feritin serum yang tinggi disebabkan oleh akumulasi zat besi dari transfusi darah berulang dan meningkatnya absorpsi zat besi. ${ }^{8}$ Selain itu, terapi kelasi yang tidak optimal pada penyandang thalassemia juga meningkatkan akumulasi zat besi. ${ }^{4}$ Semua subjek penelitian dengan kadar feritin di atas $1000 \mathrm{ng} / \mathrm{mL}$ menerima terapi kelasi dalam bentuk monoterapi dengan obat Deferoxamine atau Deferasirox. Pemeriksaan feritin dilakukan secara rutin setiap 3 bulan pada penyandang thalassemia beta yang rutin menerima transfusi darah. Walaupun demikian, baku emas untuk pengukuran kadar besi adalah pengukuran konsentrasi zat besi hati (liver iron concentration). Metode non invasif terbaik untuk pengukuran kadar besi hati adalah dengan menggunakan MRI T2*.5
Analisa statistik pada subjek penelitian menunjukkan bahwa feritin memiliki korelasi negatif dengan kadar HDL $(r=-0,317)$. Peningkatan kadar feritin serum akan diikuti oleh penurunan kadar HDL. Hal ini sesuai dengan penelitian sebelumnya oleh Suman dan Hassanin. ${ }^{5,7}$ Aktivitas pembersihan cepat oleh monosit dan makrofag yang teraktivasi oleh sitokin menyebabkan penurunan kadar HDL pada penyandang thalassemia beta mayor. ${ }^{12,13} \mathrm{Hal}$ ini dihubungkan dengan kelebihan zat besi dalam tubuh dan kerusakan hati akibat deposisi zat besi. ${ }^{13}$

Kadar HDL yang rendah merupakan salah satu faktor prediktor terjadinya penyakit kardiovaskular pada penyandang thalassemia beta mayor. ${ }^{12}$ Penyandang thalassemia beta mayor memiliki resiko penyakit kardiovaskular yang lebih tinggi dibandingkan dengan orang normal, walaupun dengan kadar kolesterol total yang normal. ${ }^{8}$ Pada penyandang thalassemia beta mayor, terjadi peningkatan resiko atherosklerosis prematur walaupun tanpa gejala klinis pada usia muda. Kadar zat besi yang tinggi di dalam darah akan menyebabkan peningkatan risiko terjadinya atherosklerosis melalui peningkatan zat radikal bebas. ${ }^{4}$

\section{Kesimpulan}

Penyandang thalassemia beta mayor memiliki gangguan profil lipid dalam bentuk kadar HDL yang rendah. Peningkatan kadar feritin serum berkorelasi dengan penurunan kadar HDL pada penyandang thalassemia beta mayor.

\section{Daftar pustaka}

1. De Baun M, Frei-Jones M, Vichinsky E. Thalassemia syndromes. Dalam: Kliegman RM, Stanton BF, St. Geme J, Schor NF, penyunting. Nelson Textbook of Pediatrics. Edisi ke-20. Philadelphia : Elsevier; 2016.h.2349-50.

2. Kwiatkowski J. $\beta$-Thalassemia: homozygous or doubly heterozygous forms (major and intermedia). Dalam: Lanzkowsky P, penyunting. Manual of Pediatric Hematology and Oncology. Edisi ke-5. Philadelphia: Elsevier; 2011.h.235-6.

3. Gursel O, Kurekci AE, Tascilar E, Ileri T, Altun D, Tapan S, $\mathrm{dkk}$. Premature atherosclerosis in children with $\beta$-thalassemia mayor. J Pediatr Hematol Oncol 2012;34:630-4.

4. Sherief LM, Dawood O, Ali A, Sherbiny HS, Kamal NM, Elshanshory M, dkk. Premature atherosclerosis in children 
Nelly Rosdiana dkk: Peningkatan kadar feritin serum memiliki korelasi negatif dengan kadar HDL pada thalassemia beta mayor

with beta-thalassemia mayor : new diagnostic marker. BMC Pediatrics 2017;17:69.

5. Suman R, Sanadhya A, Meena P, Singh J, Jain R, Meena S. Lipid profile in children of $\beta$-thalassemia mayor and their correlation with serum ferritin. Int J Contemp Pediatr 2017;4:543-7.

6. Mansi M, Aburjal TA. Lipid profile in Jordanian children with $\beta$-thalassemia mayor. Int J Hematol Oncol 2008;18:93-8.

7. Hassanin A, Gindi HD, Wakeel MA, Kassas GM, Amer AF, Shady, dkk. Disturbances of lipid profile and serum ferritin levels in thalassemic children. Curr Sci Int 2015;4:178-83.

8. Ragab S, Safan M, Sherif A. Lipid profiles in $\beta$ thalassemic children. Menoufia Med J 2014;27:66-72.

9. WHO. Serum concentrations for the assessment of iron status and iron deficiency in populations. Vitamin and Mineral Nutrition Information System. Geneva: World Health Organization; 2011. Diakses tanggal 29 Juni 2017. Tersedia di: http://who.int/vmnis/indicators/serum_ferritin.pdf.
10. Dahlan MS. Statistik untuk kedokteran dan kesehatan: deskriptif, bivariat dan multivariat, dilengkapi aplikasi menggunakan SPSS. Edisi ke-6. Jakarta: Epidemiologi Indonesia; 2014.h.223-44.

11. Sayed S, Maher S, Adel G, Hamdy L. Lipid profile in children with $\beta$-thalassemia mayor. Egpt J Haematol 2012;37:183-6.

12. Ashar S, Sultan S, Irfan SM, Sheeraz A. Serum fasting lipid profile in children and adolescents with $\beta$-thalassemia mayor in southern Pakistan. Malay J Pathol 2015;37:233-38.

13. Arica V, Anca S, Ozer C. Cevik M. Serum lipid values in children with beta thalassemia mayor. Pediatr Therapeut 2012;2:130.

14. Haghpanah S, Davani M, Samadi B, Ashrafi A, Karimi M. Serum lipid profiles in patients with beta-thalassemia mayor and intermedia in southern Iran. J Res Med Sci 2010;15:150-4.

15. Maioli M, Cuccuru GB, Pranzetti P, Pacifico A, Cherchi GM. Plasma lipids and lipoproteins pattern in beta-thalassemia major. Acta Haemat 1984;71:106-10. 